\title{
Studi Mikrotremor dengan Metode Horizontal to Vertical Spectral Ratio (HVSR) di Tapak RDE, Serpong
}

\section{Microtremor Study using Horizontal to Vertical Spectral Ratio (HVSR) Method in RDE Site, Serpong}

\author{
Eko Rudi Iswanto*, Yuni Indrawati, Theo Alvin Riyanto \\ Pusat Kajian Sistem Energi Nuklir-BATAN \\ Jalan Kuningan Barat, Mampang Prapatan, Jakarta, Indonesia, 12710 \\ *E-mail: ekorudi@ batan.go.id
}

Naskah diterima: 11 Juli 2019, direvisi: 18 November 2019, disetujui: 25 November 2019

DOI: $10.17146 /$ eksplorium.2019.40.2.5489

\begin{abstract}
ABSTRAK
Bencana alam seperti kejadian gempa bumi dapat menyebabkan kerusakan pada area tapak dan infrastruktur termasuk fasilitas reaktor nuklir. Fenomena ini perlu dipahami secara komprehensif melalui catatan sejarah karakteristik dinamik tapak. Penggunaan mikrotremor dengan metode Horizontal to Vertical Spectral Ratio (HVSR) telah digunakan secara luas dalam investigasi bawah permukaan sejak satu dekade terakhir. Tujuan penelitian ini adalah mengetahui karakteristik geologi setempat dan karakteristik dinamis bawah permukaan. Penelitian ini mengaplikasikan penggunaan mikrotremor metode HVSR di tapak Reaktor Daya Eksperimental (RDE) di Serpong. Pengukuran dilakukan di 15 lokasi, kemudian data diolah dengan metode HVSR menggunakan perangkat lunak Geopsy. Hasil analisis menunjukkan bahwa Tapak RDE mempunyai nilai frekuensi dominan antara $3,06 \mathrm{~Hz}-23,27 \mathrm{~Hz}$ dan faktor amplifikasi 1,84-6,37. Bagian timur laut dan tenggara tapak memiliki indeks kerentanan seismik yang lebih tinggi dibandingkan dengan bagian lainnya. Oleh karena itu, pilihan lokasi gedung reaktor di area barat daya sudah tepat kerena memiliki faktor amplifikasi, ketebalan sedimen, dan indeks kerentanan seismik yang relatif rendah.
\end{abstract}

Kata kunci: mikrotremor, HVSR, tapak, RDE

\begin{abstract}
Natural disaster like earthquake can cause damage to the site and the infrastructure including nuclear reactor facilities. This phenomenon needs comprehensively understood through its dynamic characteristics historical records of the site. The use of Horizontal to Vertical Spectral Ratio (HVSR) method has been widely used for subsurface investigation since last decade. The aimed of the research is to obtain local geological and subsurface dynamic characetristics. This research is applying the use of HVSR method for Experimental Power Reactor (RDE) in Serpong. The measurements are in 15 locations, and then the data is processed by using Geopsy software. The analysis result shows that the RDE site has dominant frequncy values between $3.06 \mathrm{~Hz}-23.271 \mathrm{~Hz}$ and amplification factor 1.84-6.37. The northeast and southeast areas of the site have higher seismic vulnerability index than in other area. Therefore, the selection for reactor bulding location in the southwest area is proper because it has lower amplification factor, sedimen thickness, and seismic vulnerability index.
\end{abstract}

Keywords: microtremor, HVSR, site, RDE

\section{PENDAHULUAN}

Kawasan Puspiptek Serpong, Tangerang telah disetujui sebagai lokasi rencana pembangunan Reaktor Daya Eksperimental (RDE) yang selanjutnya disebut sebagai Tapak RDE. Hal ini diperkuat dengan telah 
dikeluarkannya izin tapak dari Badan Pengawas Tenaga Nuklir (BAPETEN) pada Januari 2017. Kegiatan evaluasi tapak telah dilakukan sebelumnya dengan mempertimbangkan beberapa aspek studi, meliputi aspek kegempaan, aspek kegunungapian, aspek geoteknik dan pondasi, aspek meteorologi, aspek hidrologi, aspek kejadian akibat ulah manusia hingga aspek dispersi dan distribusi penduduk [1]. Berdasarkan katalog gempa bumi, Tapak RDE terletak di daerah Gempa Bumi Indonesia No. VI/Jawa Barat dan merupakan daerah dengan percepatan tanah yang sangat dipengaruhi oleh patahan Cimandiri. Oleh karena itu, diperlukan kajian mendalam atas penerimaan tapak dari semua bahaya ekternal khususnya aspek kegempaan.

Kerusakan yang diakibatkan gempa bumi selain tergantung pada kekuatan dan kualitas bangunan, besarnya magnitudo dan jarak gempa, juga tergantung pada karakteristik bawah permukaan [2, 3]. Pemodelan kondisi bawah permukaan sudah dilakukan pada kegiatan survei sebelumnya dengan menggabungkan hasil analisis data mikrotremor single station dan mikrotremor array [4].

Pada penelitian ini dilakukan pengukuran ulang yang lebih spesifik di lokasi rencana gedung turbin dan sekitarnya dengan menggunakan metode pasif, yaitu menggunakan sumber alami gelombang seismik berupa pengukuran mikrotremor single station. Analisis data hasil pengukuran dilakukan dengan menggunakan metode Horizontal to Vertical Spectral Ratio (HVSR). Metode HVSR adalah suatu metode yang digunakan untuk menghitung rasio spektrum komponen horizontal terhadap komponen vertikal dari gelombang mikrotremor. Metode ini bersifat pasif sehingga efektif dan murah untuk area penelitian yang padat penduduk seperti halnya di perkotaan [5]. Selain itu, metode ini juga merupakan salah satu cara yang efektif untuk mengkarakterisasi faktor amplifikasi akibat gempa lokal [6]. Tujuan dari penelitian ini adalah untuk mengetahui karakteristik geologi setempat dan karakteristik dinamis bawah permukaan yang berupa nilai frekuensi predominan $\left(\mathrm{f}_{0}\right)$, faktor amplifikasi $\left(\mathrm{A}_{0}\right)$ [7, 8], dan indeks kerentanan sesimik $\left(\mathrm{K}_{\mathrm{g}}\right)$.

\section{TINJAUAN PUSTAKA \\ Tapak RDE}

Wilayah penelitian berada di kawasan Puspiptek, Serpong dengan koordinat batasan penelitian adalah $6,355^{\circ}$ LS hingga $6,360^{\circ}$ LS; $106,659^{\mathrm{O}}$ BT hingga $106,667^{\mathrm{O}} \mathrm{BT}$. Secara geologi, batuan di Tapak RDE merupakan bagian dari produk gunung api muda Gunung Gede Salak. Batuan tersebut tersusun oleh Formasi Serpong (Tpss), Formasi Bojongmanik (Tmbl), Formasi Genteng (Tpg), Aluvial (Qa), Kipas Aluvial (Qav3) dan Batuan Gunung Muda (Qv1) sebagaimana dapat dilihat pada Gambar 1.

Formasi Serpong (Tpss) disusun oleh perselingan tuf kasar dengan konglomerat batuapung, berwarna putih terang, kemas terbuka, sortasi baik, didominasi oleh matriks berupa tuf kasar dan fragmen batuapung berukuran $2-5 \mathrm{~cm}$, membentuk perselingan dengan tuf kasar, kontak berangsur, perlapisan berarah $\mathrm{N} 130^{\mathrm{O}} \mathrm{E} / 7^{\mathrm{O}}$. Formasi Bojongmanik (Tmbl) disusun oleh perselingan batupasir, batulempung, dan batugamping. Batugamping berwarna abuabu putih, terang, sangat keras, kristalin, membentuk perselingan dengan batugamping pasiran. Pada formasi ini terdapat sisipan batupasir, berwarna abu-abu gelap, karbonan, pasir sedang sampai kasar, memiliki 
ketebalan sekitar $20 \mathrm{~cm}$. Arah jurus dan kemiringan perlapisan $\mathrm{N} 35^{\circ} \mathrm{E} / 20^{\circ}$ dan di beberapa tempat terdapat lapisan tipis karbonan atau lignit. Formasi Genteng (Tpg) didominasi oleh batuan hasil produk vulkanik. Lapukannya sangat khas berwarna merah sampai merah kecoklatan dan menunjukkan perlapisan mendatar sebagai hasil dari perulangan material vulkanik yang diendapkan di daerah darat atau litoral. Formasi Genteng disusun oleh tuf berwarna coklat-coklat tua, tuf halus, tuf kasar dan lapilli, berlapis horizontal antara yang kasar dan halus, scoria dan batuapung, dengan tingkat pelapukan sedang sampai tinggi. Endapan Aluvial (Qa), berupa endapan sungai, banyak ditemukan di sepanjang aliran Sungai Cisadane dan sungai kecil di sekitarnya dengan material penyusun berupa lempung, lanau, pasir, kerikil, kerakal, dan bongkah. Kipas Aluvial (Qav3) merupakan material hasil pengendapan dari material vulkanik yang sebelumnya ada dan terendapkan (rework) melalui mekanisme aliran mulai dari arah selatan ke utara mengikuti landaian topografinya. Kipas aluvial disusun oleh konglomerat, tuf, dan batupasir. Batuan gunung muda (Qv1) disusun oleh breksi vulkanik berwarna abuabu kehitaman, dominan matriks, komponen kerakal-bongkah, fragmen monomik berupa basalt, pemilahan buruk, porositas sedang dan tuf berwarna putih kekuningan-kemerahan, halus, kekerasan sedang.

Variasi jenis batuan di daerah penelitian dapat mempengaruhi amplifikasi gempa. Secara umum, gelombang gempa yang merambat pada tanah dengan kondisi geologi berupa endapan atau sedimen yang tebal akan mengalami amplifikasi.

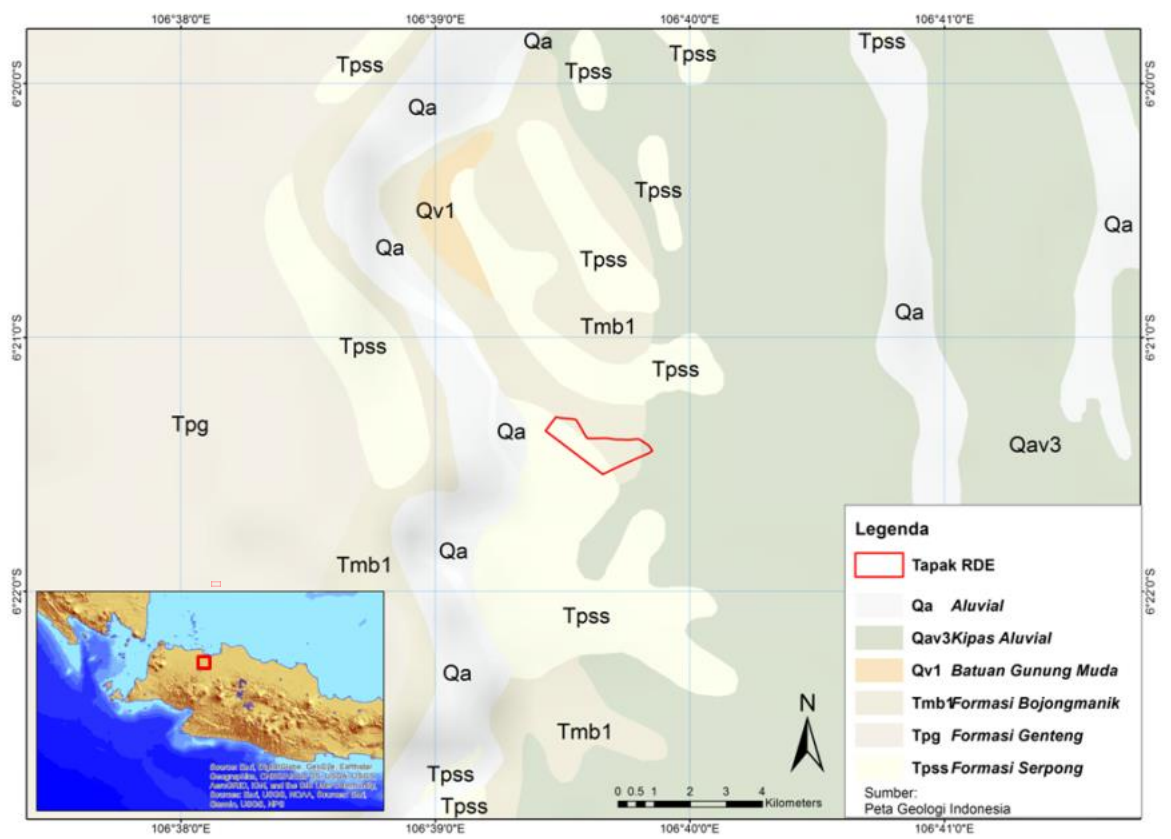

Gambar 1. Peta Geologi Daerah Penelitian.

\section{Metode HVSR}

Mikrotremor adalah getaran tanah yang sangat kecil dan terus menerus dari berbagai macam sumber getaran baik berupa gangguan buatan maupun sumber alam. Gangguan buatan dapat berupa aktivitas manusia, mesin industri, dan lain sebagainya. Sementara itu gangguan yang bersumber dari alam dapat berupa angin dan gelombang laut. Getaran tanah dapat disebut juga sebagai vibrasi tanah 
dengan nilai amplitude displacement sekitar 0,1-1 mikron dan amplitude velocity 0,001$0,01 \mathrm{~cm} / \mathrm{dt}$ [9]. Data yang direkam berasal dari ambient noise yang dapat memberikan gambaran respon spektral tanah dari suatu daerah studi [10]. Pada batuan keras, gerak partikel pada komponen horizontal $(\mathrm{H})$ dan komponen vertikal (V) mendekati nilai yang sama, sedangkan pada batuan lunak komponen horizontalnya mengalami penguatan.

Secara matematik, frekuensi dasar dari suatu lokasi dapat dihitung melalui perbandingan $\mathrm{H}$ dengan $\mathrm{V}$ dari spektrum getar alami dengan $\omega$ adalah frekuensi angular, S adalah gelombang sekunder, NS adalah arah utara-selatan, dan EW adalah arah timur-barat sebagaimana dituliskan dalam persamaan (1) [11].

$$
\frac{\mathrm{H}}{\mathrm{V}}=\left[\frac{\mathrm{S}^{2}(\omega) \mathrm{NS}+\mathrm{S}^{2}(\omega) \mathrm{EW}}{2 \mathrm{~S}^{2}(\omega) \mathrm{V}}\right]^{1 / 2}
$$

Indeks Kerentanan Seismik menggambarkan tingkat kerentanan lapisan tanah permukaan terhadap deformasi saat terjadi gempa bumi. Nilai Indeks Kerentanan Seismik berkaitan langsung dengan kondisi geomorfologis [12]. Indeks kerentanan seismik di suatu daerah dan tingkat resiko gempa bumi terhadap kerusakan akibat gempa bumi menunjukkan adanya hubungan yang linier [13]. Indeks Kerentanan Seismik dihitung dengan persamaan sebagai berikut:

$$
K_{g}=\frac{A_{o}^{2}}{f_{o}}
$$

Nilai $\mathrm{Kg}$ adalah Indeks Kerentanan Seismik (10-6 $\left.\mathrm{dt}^{2} / \mathrm{cm}\right), \mathrm{A}_{0}$ adalah faktor amplifikasi $(\mathrm{dt})$, dan $\mathrm{f}_{0}$ adalah frekuensi predominan $(\mathrm{Hz})$.

Indeks Kerentanan Seismik yang tinggi umumnya ditemukan pada tanah dengan litologi batuan sedimen yang lunak. Nilai indeks yang tinggi menggambarkan bahwa daerah tersebut rentan terhadap gempa dan jika terjadi gempa dapat mengalami goncangan yang kuat sehingga tingkat kerusakan juga akan semakin besar [14, 15]. Sebaliknya, nilai yang kecil umumnya ditemukan pada tanah dengan litologi batuan penyusun yang kokoh sehingga saat terjadi gempa tidak mengalami banyak goncangan. Tabel 1-3 menunjukkan klasifikasi tanah dan nilai indeks kerentanan seismik untuk menganalisis ataupun menginterpretasi peta indeks kerentanan seismik.

\begin{tabular}{|c|c|c|c|c|}
\hline \multicolumn{2}{|c|}{$\begin{array}{c}\text { Klasifikasi } \\
\text { Tanah }\end{array}$} & \multirow{2}{*}{$\begin{array}{c}\text { Frekuensi } \\
\text { Predominan } \\
(\mathbf{H z}) \\
\end{array}$} & \multirow[t]{2}{*}{ Klasifikasi Kanai } & \multirow[t]{2}{*}{ Deskripsi } \\
\hline Tipe & Jenis & & & \\
\hline \multirow{2}{*}{$\begin{array}{l}\text { Tipe } \\
\text { IV }\end{array}$} & $\begin{array}{l}\text { Jenis } \\
\text { I }\end{array}$ & $6,667-20$ & $\begin{array}{l}\text { Batuan tersier atau lebih tua. } \\
\text { Terdiri dari batuan Hard sandy, } \\
\text { gravel,dll. }\end{array}$ & $\begin{array}{l}\text { Ketebalan sedimen permukaan sangat } \\
\text { tipis, didominasi oleh batuan keras. }\end{array}$ \\
\hline & Jenis II & $10-4$ & $\begin{array}{l}\text { Batuan alluvial, dengan ketebalan } \\
\text { 5m, Terdiri dari sandy - gravel, } \\
\text { sandy hard clay, loom, dll. }\end{array}$ & $\begin{array}{l}\text { Ketebalan sedimen permukaan } \\
\text { termasuk dalam kategori menengah, } \\
5-10 \text { meter. }\end{array}$ \\
\hline $\begin{array}{l}\text { Tipe } \\
\text { III }\end{array}$ & $\begin{array}{l}\text { Jenis } \\
\text { III }\end{array}$ & $2,5-4$ & $\begin{array}{l}\text { Batuan alluvial, dengan ketebalan } \\
>5 \mathrm{~m} \text {. Terdiri dari sandy - } \\
\text { gravel,sandy hard clay, loam, dll }\end{array}$ & $\begin{array}{l}\text { Ketebalan sedimen permukaan } \\
\text { termasuk dalam kategori tebal, sekitar } \\
\text { 10-30 meter. }\end{array}$ \\
\hline $\begin{array}{l}\text { Tipe } \\
\text { II }\end{array}$ & $\begin{array}{l}\text { Jenis } \\
\text { IV }\end{array}$ & $<2,5$ & $\begin{array}{l}\text { Batuan alluvial yang terbentuk } \\
\text { dari sedimentasi delta, top soil, } \\
\text { lumpur, dll dengan kedalaman } 30 \\
\text { m atau lebih. }\end{array}$ & $\begin{array}{l}\text { Ketebalan sedimen permukaan sangat } \\
\text { tebal }\end{array}$ \\
\hline
\end{tabular}

Tabel 1. Klasifikasi tanah berdasarkan nilai frekuensi predominan mikrotremor [15]. 
Tabel 2. Klasifikasi Tanah menurut Kanai dan Omote-Nakajima berdasarkan periode (T) [15].

\begin{tabular}{|c|c|c|c|c|}
\hline \multicolumn{2}{|c|}{ Klasifikasi Tanah } & \multirow[b]{2}{*}{$\begin{array}{l}\text { Periode/T } \\
\quad(d t)\end{array}$} & \multirow[b]{2}{*}{ Keterangan } & \multirow[b]{2}{*}{ Karakter } \\
\hline Kanai & $\begin{array}{c}\text { Omote- } \\
\text { Nakajima }\end{array}$ & & & \\
\hline Jenis I & \multirow[b]{2}{*}{ Jenis A } & $0,05-0,15$ & $\begin{array}{l}\text { Batuan tersier atau lebih tua. Terdiri } \\
\text { dari batuan hard sandy, gravel, dll. }\end{array}$ & \\
\hline Jenis II & & $0,10-0,25$ & $\begin{array}{l}\text { Batuan alluvial dengan ketebalan } 5 \mathrm{~m} \text {. } \\
\text { Terdiri dari sandy-gravel, sandy hard } \\
\text { clay, loa,, dll. }\end{array}$ & Keras \\
\hline Jenis III & Jenis B & $0,25-0,40$ & $\begin{array}{l}\text { Batuan alluvial hampir sama dengan } \\
\text { jenis II. Hanya dibedakan oleh adanya } \\
\text { formasi bluff. }\end{array}$ & Lunak \\
\hline Jenis IV & Jenis C & Lebih dari 0,40 & $\begin{array}{l}\text { Batuan alluvial yang terbentuk dari } \\
\text { sedimentasi delta, top soil, lumpur, } \\
\text { dll. Dengan kedalaman } 30 \mathrm{~m} \text { atau } \\
\text { lebih. }\end{array}$ & Sangat Lunak \\
\hline
\end{tabular}

Tabel 3. Klasifikasi nilai amplifikasi [15].

\begin{tabular}{ccc}
\hline Zona & Klasifikasi & $\begin{array}{c}\text { Faktor } \\
\text { Amplifikasi }\end{array}$ \\
\hline 1 & Rendah & $\mathrm{A}<3$ \\
2 & Sedang & $3 \leq \mathrm{A}<6$ \\
3 & Tinggi & $6 \leq \mathrm{A}<9$ \\
4 & Sangat Tinggi & $>9$ \\
\hline
\end{tabular}

\section{METODOLOGI}

Pengukuran mikrotremor dilakukan pada 15 titik ukur di Tapak RDE, Serpong menggunakan seismometer tipe McSEIS-MT NEO merk OYO. Sebaran titik ukur memiliki interval berkisar 100-300 m (Gambar 2). Data lapangan hasil pengukuran kemudian diolah menggunakan metode HVSR melalui software Geopsy dengan alur sebagaimana dapat dilihat pada Gambar 3.

Langkah pengolahan data dapat dijelaskan sebagai berikut:

1. Membuka data mentah yang terdiri dari tiga komponen dan masih dalam fungsi waktu di software Geopsy.
2. Proses fast fourier transform (fft) untuk mengubah data ke dalam domain frekuensi.

3. Melakukan proses windowing dengan memilih sinyal yang stasioner.

4. Memasukkan nilai dari parameterparameter pengolahan data, antara lain jenis smoothing Konno-Ohmachi dengan koefisien bandwith 40 dan cosine taper $5 \%$ serta memilih squared average untuk perhitungan pada komponen horizontal.

5. Melakukan ploting dari rata-rata spektrum HVSR. Analisis menghasilkan suatu puncak H/V yang menunjukkan nilai frekuensi predominan di sumbu $\mathrm{x}$ dan faktor amplifikasi pada sumbu y yang kemudian digunakan untuk menghitung indeks kerentanan seismik. 


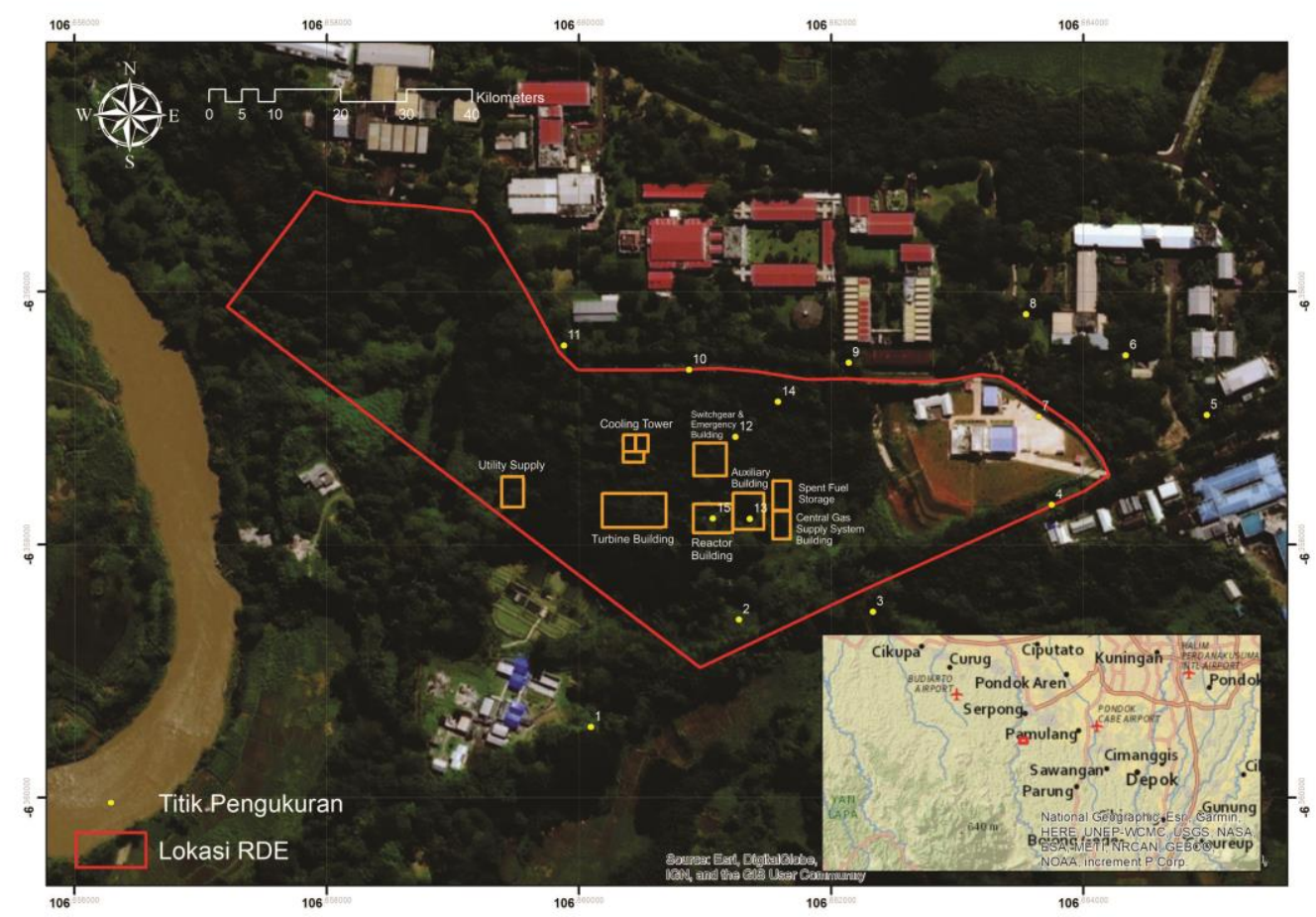

Gambar 2. Lokasi Titik-Titik Pengukuran Mikrotremor.

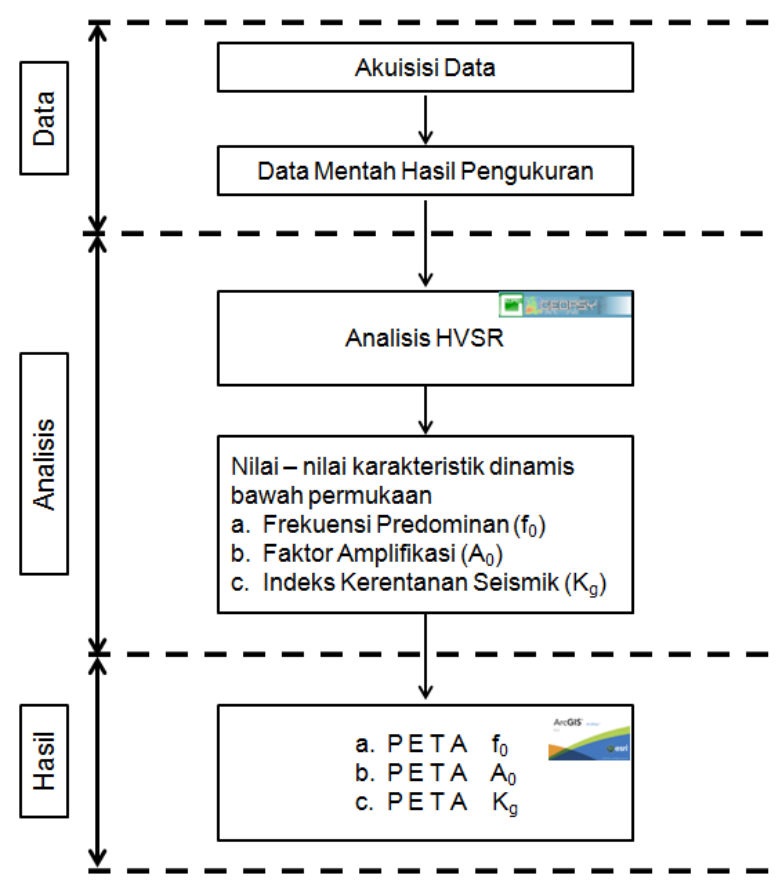

Gambar 3. Alur Pengolahan Data Mikrotremor dengan Metode HVSR.

\section{HASIL DAN PEMBAHASAN}

\section{Frekuensi Predominan}

Hasil analisis HVSR di sekitar Tapak RDE menunjukkan bahwa nilai frekuensi predominan beragam mulai dari $3,06 \mathrm{~Hz}$ hingga 23,27 Hz. Plot sebaran nilai frekuensi predominan menunjukkan nilai frekuensi predominan tertinggi berada di titik ukur nomor 2, sedangkan nilai frekuensi predominan terendah berada di titik ukur nomor 7 (Gambar 4). Hal ini menunjukkan 
bahwa deskripsi tanah di titik ukur nomor 2 berupa batuan Tersier yang tersusun oleh batuan keras. Ditinjau dari kolom stratigrafi, lokasi titik ini berada pada Formasi Bojongmanik (Tmbl) yang tersusun oleh perselingan batupasir, batulempung dan batugamping. Lain halnya pada titik ukur nomor 7, area tersebut berada di Kipas Aluvial (Qav3) yang merupakan material hasil pengendapan dari material vulkanik, tersusun oleh konglomerat, tuf dan batuapasir. Hal ini berarti bahwa titik ukur tersebut memiliki lapisan sedimen yang lebih tebal jika dibandingkan dengan titik ukur yang lain. Suatu daerah dengan karakteristik nilai frekuensi predominan rendah

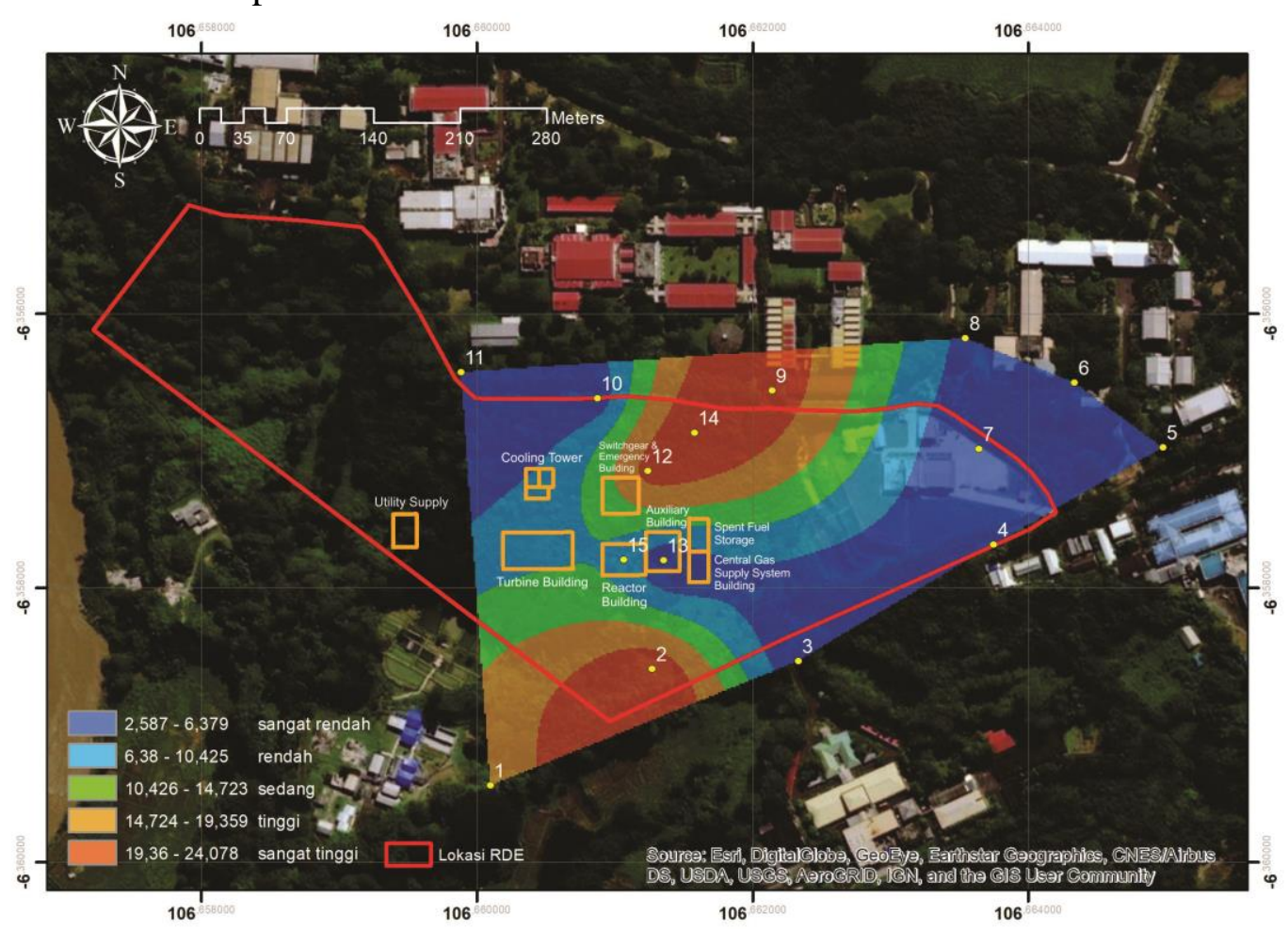

Gambar 4. Sebaran frekuensi predominan di sekitar Tapak RDE.

\section{Faktor Amplifikasi}

Amplifikasi merupakan perbesaran gelombang seismik yang terjadi karena adanya perubahan yang signifikan antar lapisan yaitu dari medium keras ke medium yang lebih lunak [16]. Analisis HVSR di sekitar Tapak RDE menunjukkan bahwa menunjukkan bahwa daerah tersebut rentan terhadap bahaya getaran gelombang gempa bumi periode panjang yang dapat mengakibatkan kerusakan pada bangunan seperti gedung, jalan, dan infrastruktur lainnya.

Hasil klasifikasi tanah di daerah penelitian berdasarkan Tabel 1 termasuk dalam klasifiksi tanah jenis III. Sementara itu, berdasarkan Tabel 2 termasuk klasifikasi tanah jenis C. Hal ini berarti bahwa deskripsi tanah di titik ukur nomor 7 berupa batuan aluvial yang terbentuk dari sedimentasi delta, lumpur, atau lainnya yang bersifat sangat lunak. 
tenggara Tapak RDE mempunyai nilai amplifikasi yang lebih tinggi jika dibandingkan dengan area barat laut. Hal ini sesuai dengan kondisi geologi, bahwa area ini berada di Formasi Serpong (Tpss) dan Kipas Aluvial (Qav3) yang merupakan batuan lebih muda dibanding Formasi Bojongmanik (Tmbl). Formasi Serpong (Tpss) tersusun dari perselingan tuf kasar dengan konglomerat batuapung sedangkan Kipas Aluvial tersusun oleh konglomerat, tuf, dan batupasir yang sebagian besar terdiri dari tanah lunak sehingga gelombang seismik yang melintasi area tersebut akan mengalami penguatan. Berdasarkan klasifikasi nilai amplfikasi, sebagian besar area Tapak RDE mempunyai faktor amplifikasi di bawah 3 dan sebagian kecilnya mempunyai faktor amplifikasi di atas 3 sampai lebih kecil dari 6 sehingga area Tapak RDE termasuk daerah dengan nilai amplifikasi sedang.

\section{Indeks Kerentanan Seismik}

Indeks Kerentanan Seismik diperoleh dari kuadrat faktor amplifikasi dibagi dengan nilai frekuensi predominan. Tinggi rendahnya nilai Indeks Kerentanan Seismik sebanding dengan tingkat kerusakan suatu daerah. Nilai Indeks Kerentanan Seismik tinggi diperoleh dari area yang mempunyai nilai amplifikasi tinggi dengan nilai frekuensi dominan rendah. Semakin tebal lapisan sedimen suatu daerah akan mengakibatkan amplifikasi saat terjadi gempa bumi [17]. Hal ini sesuai dengan sebaran nilai Indeks Kerentanan Seismik di sekitar calon Tapak RDE dengan rentang mulai dari 0,28 hingga 9,26. Nilai tertinggi berada di titik ukur nomor 6 sedangkan nilai terendah di titik ukur nomor 12. Nilai indeks kerentanan seismik lebih besar dari 20 akan menghasilkan deformasi atau kerusakan yang besar. Pada area Tapak RDE tidak ditemukan titik ukur yang mempunyai nilai Indeks Kerentanan Seismik di atas 20 (Gambar 6).

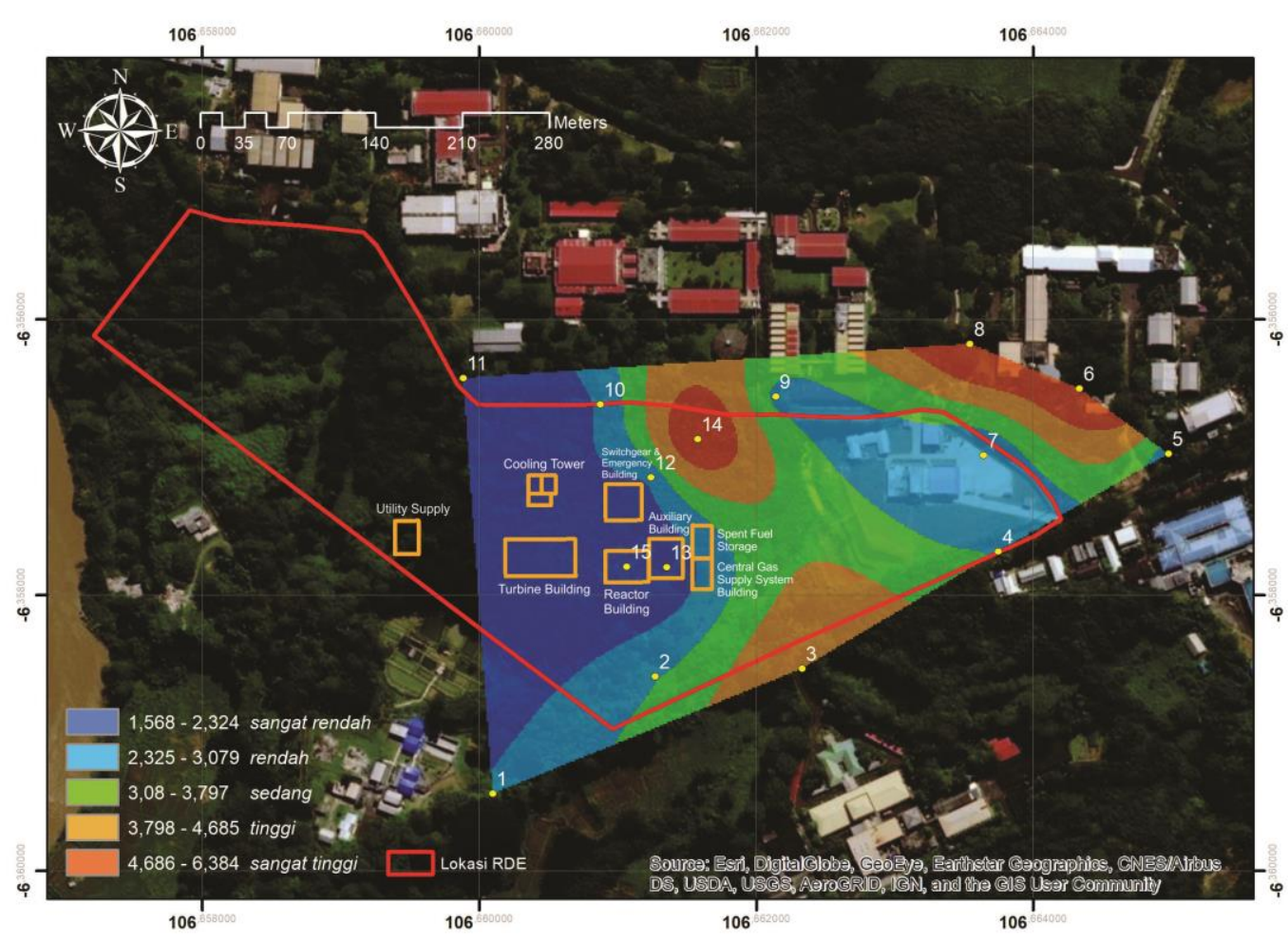

Gambar 5. Peta amplifikasi di sekitar Tapak RDE. 


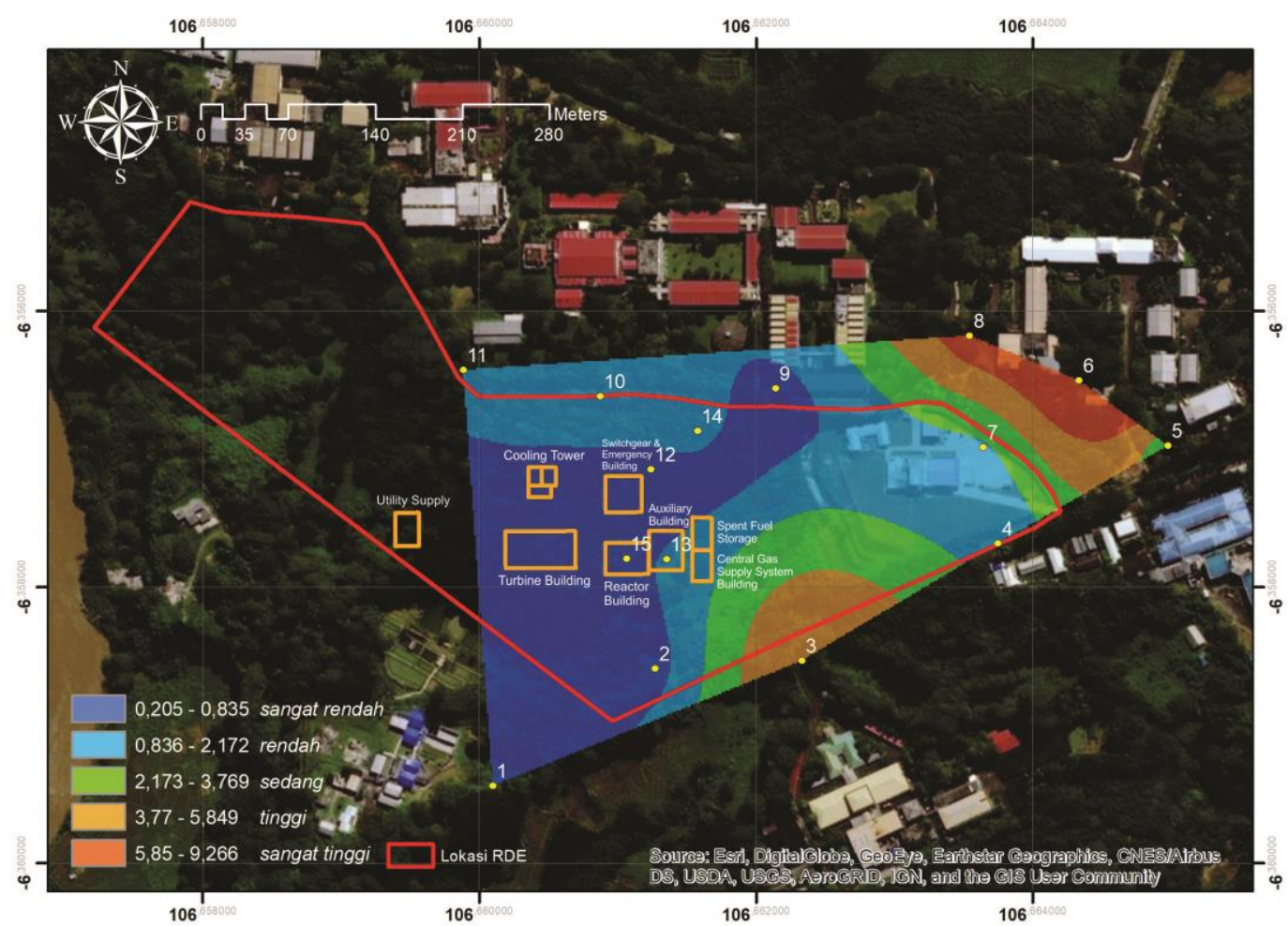

Gambar 6. Peta indeks kerentanan seismik di sekitar Tapak RDE.

\section{KESIMPULAN}

Pengukuran mikrotremor di sekitar Tapak RDE menunjukkan beberapa karakteristik tapak yaitu frekuensi predominan, faktor amplifikasi, dan Indeks Kerentanan Sesimik. Ditinjau dari frekuensi predominannya, area sekitar Tapak RDE mempunyai nilai frekuensi predominan antara $3,06 \mathrm{~Hz}$ hingga $23,27 \mathrm{~Hz}$, nilai amplifikasi berkisar antara 1,84 hingga 6,37, dan nilai indeks kerentanan seismik berkisar antara 0,28 hingga 9,26. Peta amplifikasi dan Indeks Kerentanan Seismik menunjukkan bahwa area timur laut dan tenggara Tapak RDE merupakan area dengan tingkat amplifikasi dan kerentanan seismik yang lebih tinggi. Secara kondisi geologi area tersebut merupakan kipas aluvium berupa sedimen lunak. Sebagian besar peta sebaran nilai frekuensi, amplifikasi, dan Indeks Kerentanan Seismik sesuai dengan informasi geologi area penelitian. Pemilihan area barat daya dari
Tapak RDE (sekitar titik ukur 13 dan 15) sebagai lokasi gedung reaktor sudah tepat karena area ini memiliki faktor amplifikasi, ketebalan sedimen, dan indeks kerentanan seismik yang relatif rendah dibanding area lainnya.

\section{UCAPAN TERIMA KASIH}

Penelitian ini didukung dan didanai oleh Pusat Kajian Sistem Energi Nuklir, Badan Tenaga Nuklir Nasional (PKSEN-BATAN) Tahun Anggaran 2019. Para penulis menyatakan bahwa sebagai kontributor utama dalam kegiatan penelitian ini adalah Eko Rudi Iswanto, meliputi kegiatan pengukuran, pengolahan dan analisis data lapangan, hingga penulisan makalah.

\section{DAFTAR PUSTAKA}

[1] BATAN, "Laporan Evaluasi Tapak RDE Aspek Geoteknik dan Pondasi," Jakarta, 2016.

[2] Sungkono and B. J. Santosa., "Karakterisasi Kurva Horizontal-To-Vertical Spectral Ratio: Kajian Literatur Dan Permodelan,” J. Neutrino, 
vol. 4 , no. $1,2011$.

[3] Sunaryo, H. U. Mala, and A. Prasetio, "Earthquake Microzonation Study on Batu Besi Dam of Nuha, East Luwu, South Sulawesi, Indonesia," Int. J. GEOMATE, vol. 15, no. 48, pp. 148-154, 2018.

[4] BATAN, "Laporan Evaluasi Tapak Aspek Kegempaan," Jakarta, 2016.

[5] P. Gueguen, J. L. Chatelain, B. Guillier, and H. Yepes, "An indication of the soil topmost layer response in Quito ( Ecuador ) using noise $\mathrm{H} / \mathrm{V}$ spectral ratio," Soil Dyn. Earthq. Eng., vol. 19, pp. 127-133, 2000.

[6] R. Carniel, P. Malisan, F. Barazza, and S Grimaz, "Improvement of HVSR technique by wavelet analysis," Soil Dyn. Earthq. Eng., vol. 28, no. 4, pp. 321-327, 2008.

[7] M. Herak, "Model HVSR - A Matlab tool to model horizontal-to-vertical spectral ratio of ambient noise," Comput. Geosci., vol. 34, pp. 1514-1526, 2008.

[8] J. Saita, M. L. T. Bautista, and Y Nakamura, "On Relationship Between The Estimated Strong Motion Characteristics Of Surface Layer And The Earthquake Damage," in 13 th World Conference on Earthquake Engineering, 2004, no. 905 , pp. 1-7.

[9] M. Mirzaoglu and Ü. Dýkmen, "Application of microtremors to seismic microzoning procedure," J. Balk. Geophys. Soc., vol. 6, no. No. 3, pp. 143156, 2003.

[10] M Sutrisna, C. Sulaeman, and N. D. Ardi, "Metode Mikrotremor untuk Mikrozonasi Gempa Bumi di Kota Cilacap," J. online Fis., vol. 3, no. 2, 2015.

[11] J. W. Lane, E. A. White, G. V. Steele and J. C. Cannia, "Estimation of Bedrock Depth Using the Horizontal-to-vertical (H/V) Ambient-noise Seismic Method," in Symposium on the Application of Geophysics to Engineering and
Environmental Problems 2008, Denver, Colorado, Society of Exploration Geophysicists, 2008, pp. 490-502.

[12] A. I. Hadi, M. Farid, and Y. Fauzi, "Pemetaan Percepatan Getaran Tanah Maksimum dan Kerentanan Seismik Akibat Gempa Bumi untuk Mendukung Rencana Tata Ruang dan Wilayah (RTRW) Kota Bengkulu," Simetri J. Ilmu Fis. Indones., vol. 1 Nomor 2, September, pp. 81-86, 2012.

[13] Saaduddin, Sismanto, and Marjiyono, "Pemetaan Indeks Kerentanan Sesimik Kota Padang Sumatera Barat dan Korelasinya dengan Titik Kerusakan Gempa Bumi 30 September 2009," in Seminar Nasional Kebumian Ke-8, 2015, pp. 459-466.

[14] Daryono, Sutikno, J Sartohadi, Dulbahri, and K. S. Brotopuspito, "Pengkajian Local Site Effect di Graben Bantul Menggunakan Indeks Kerentanan Seismik Berdasarkan Pengukuran Mikrotremor," J. Kebencanaan Indones., vol. 2, no. No.1, pp. 456-467, 2009

[15] S. S. Arifin, "Penentuan Zona Rawan Guncangan Bencana Gempa Bumi Berdasarkan Analisis Nilai Amplifikasi HVSR Mikrotremor dan Analisis Periode Dominan Daerah Liwa dan Sekitarnya," J. Geofis. Eksplor., vol. 2, no. 1, pp. 30-40, 2018.

[16] N. Sitorus, S. Purwanto, and W. Utama "Analisis Nilai Frekuensi Natural dan Amplifikasi Desa Olak Alen Blitar Mengguakan Metode Mikrotremor HVSR," J. Geosaintek, vol. 03, no. 02, pp. 89-92, 2017.

[17] R. A. Murdiantoro, Sismanto, and Marjiyono "Pemetaan Daerah Rawan Kerusakan Akibat Gempabumi di Kotamadya Denpasar dan Sekitarnya dengan Menggunakan Analisis Mikrotremor Studi Kasus : Gempabumi Seririt 14 Juli 1976," J. Fis. Indones., vol. 20 No.2, no. 2, pp. 36-41, 2016. 